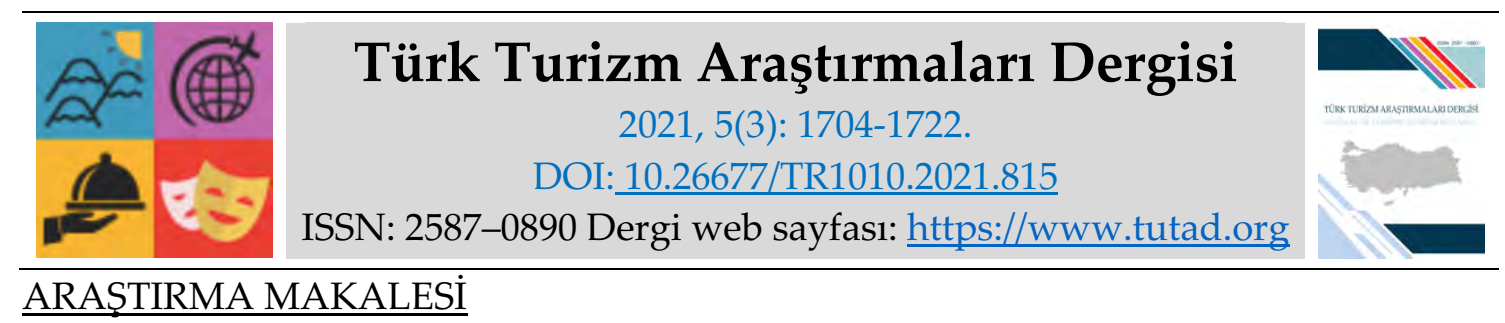

\title{
Hizmet Kalitesi ile Yenilenme Arasındaki İlişkinin İncelenmesi: Hatay Arkeoloji Müzesi Örneği
}

Bertan KALABA, Yüksek Lisans Öğrencisi, İskenderun Teknik Üniversitesi, Lisansüstü Eğitim Enstitüsü, Hatay, e-posta: bertankalaba@hotmail.com ORCID: https://orcid.org/0000-0001-9490-9087

Dr. Öğr. Üyesi Çağrı SAÇLI, Mersin Üniversitesi, Turizm Fakültesi, Mersin, e-posta: sacli.cagri@gmail.com

ORCID: https://orcid.org/0000-0001-7771-8190

\section{Öz}

Hizmet kalitesi, bir işletmenin müşteri beklentilerini hangi ölçüde karşılayabildiğini açıklayan bir kavram olarak tanımlanırken, yenilenme kavramı ise bireylerin gerçekleştirdikleri eylemlere karşı kişisel olarak yenilenmiş olma tutumlarıyla alakalıdır. Bu iki kavramın ortak özelliği ise; alınan bir hizmete, dahil olunan bir etkinliğe vb. durumlara yönelik, doğrudan bireylerin bakış açısına ve kişisel değerlendirmelerine dayalı kavramlar olmalarıdır. Ancak literatürde birbiriyle ortak noktaları bulunan bu iki yapının arasındaki ilişkiyle ilgili önemli bir eksiklik göze çarpmaktadır. Araştırmanın ana amacı, hizmet kalitesi ile yenilenme kavramları arasındaki ilişkiyi incelemektir. Araştırmanın evrenini 2020 yılında Hatay Arkeoloji Müzesini ziyaret eden bireyler oluşturmaktadır. Araştırmada veri toplama aracı olarak anket tekniği kullanılmış ve 404 geçerli anket verisi elde edilmiştir. Elde edilen verilere araştırmanın amaçları doğrultusunda; frekans analizi, geçerlilik ve güvenirlik testleri, normallik testi, korelasyon (ilişki) ve regresyon (etki) analizleri uygulanmıştır. Yapılan analizler sonucunda, katılımcıların hizmet kalitesi algıları ile yenilenme düzeyleri arasında pozitif yönlü ve istatistiki açıdan anlamlı bir ilişkinin bulunduğu tespit edilmiştir. Ayrıca bu ilişkiden hareketle yapılan regresyon analizi sonucunda, katılımcıların hizmet kalitesi algılarının yenilenme düzeyleri üzerinde pozitif yönde ve istatistiki açıdan anlamlı bir etkisinin bulunduğu tespit edilmiştir.

* Bu çalışma Bertan KALABA'nın 2021 yılında Dr. Öğr. Üyesi Çağrı SAÇLI'nın danışmanlığında gerçekleştirdiği “Hizmet Kalitesi ile Yenilenme Arasındaki İlişkinin İncelenmesi: Hatay Arkeoloji Müzesi Örneği” başlıklı yüksek lisans tezinden türetilmiştir.

Anahtar Kelimeler: Kültür Turizmi, Müze, Hizmet Kalitesi, Rekreasyon, Yenilenme.

Makale Gönderme Tarihi: 17.06.2021

Makale Kabul Tarihi: 02.09.2021

\section{Önerilen Atıf:}

Kalaba, B. ve Saçlı, Ç. (2021). Hizmet Kalitesi ile Yenilenme Arasındaki İlişkinin İncelenmesi: Hatay Arkeoloji Müzesi Örneği, Türk Turizm Araştırmaları Dergisi, 5(3): 1704-1722.

(c) 2021 Türk Turizm Araştırmaları Dergisi. 


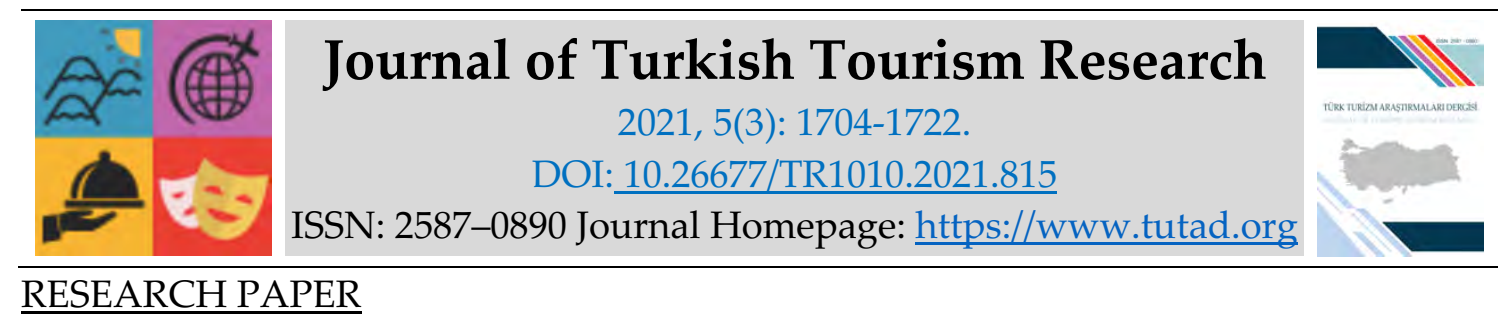

\title{
Examining The Relationship Between Service Quality and Renewal: The Case of Hatay Archeology Museum
}

Bertan KALABA, MSc. Student, İskenderun Technical University, Graduate Education Institute, Hatay, e-mail: bertankalaba@hotmail.com

ORCID: https://orcid.org/0000-0001-9490-9087

Assistant Prof. Dr. Çağrı SAÇLI, Mersin University, Faculty of Tourism, Mersin, e-mail: sacli.cagri@gmail.com

ORCID: https://orcid.org/0000-0001-7771-8190

\begin{abstract}
While service quality is defined as a concept that explains the extent to which a business can meet customer expectations, the concept of re-creation is related to the attitudes of individuals to be personally renewed towards the actions they do. The common feature of these two concepts is; they are concepts based directly on individuals' perspectives and personal evaluations for a service received, an activity involved, etc. However, there is an important deficiency in the relationship between these two structures, which have common points in the literature. The main purpose of the research is to examine the relationship between service quality and renewal concepts. The population of the research consists of individuals visiting Hatay Archeology Museum in 2020. Survey technique was used as a data collection tool in the research and 404 valid survey data were obtained. In line with the purposes of the research, the data obtained; frequency analysis, validity and reliability tests, normality test, correlation (correlation) and regression (effect) analyzes were applied. As a result of the analysis, it was determined that there was a positive and statistically significant relationship between the service quality perceptions of the participants and their renewal levels. In addition, as a result of the regression analysis based on this relationship, it was determined that the service quality perceptions of the participants had a positive and statistically significant effect on the renewal levels.
\end{abstract}

Keywords: Culture Tourism, Museum, Quality of Service, Recreation, Renewal.

Received: 17.06 .2021

Accepted: 02.09.2021

Suggested Citation:

Kalaba, B. and Saçlı, Ç. (2021). Examining The Relationship Between Service Quality and Renewal: The Case of Hatay Archeology Museum, Journal of Turkish Tourism Research, 5(3): 17041722.

(c) 2021 Türk Turizm Araştırmaları Dergisi. 


\section{Gíriş}

Hizmet kalitesi, bir kurum veya işletmenin başarılı olabilmesi için en önemli belirleyicilerden birisidir (Berry, Parasuraman ve Zeithalm, 1988). Hizmet kalitesinin işletmeler açısından oldukça önemli bir kavram olması sebebiyle, birçok araştırmacı (Parasuraman vd., 1985, 1988; Cronin ve Taylor, 1992, 1994; Frochot ve Hughes, 2000; Allen, 2001; Hsieh, 2010; Hsieh vd., 2015) müşterilerin/ziyaretçilerin hizmet kalitesi algılarını ölçülebilir kılmak adına çeşitli ölçekler geliştirmiştir.

Bireyler çeşitli zamanlarda arınmak, dinlenmek, uzaklaşmak, iyi vakit geçirmek, mutlu olmak, farklı şeyler deneyimlemek, sağlık, kendini geliştirmek ve içsel tatminlerini sağlamak gibi amaçlarla, çeşitli rekreasyon etkinliklerine katılmaktadırlar (Karaküçük, 2014:52). Koçak ve Eryılmaz (2018) yaptıkları çalışmada, farklı rekreasyon faaliyetlerinin performansını ölçmek ve bireylerin yenilenme (re-creation) düzeylerini gözlenebilir kılmak amacıyla "yenilenme ölçeği" adını verdikleri yeni bir ölçeği literatüre kazandırmışlardır. Buradaki amaç; mutlu olma, arınma, dinlenme, farklı şeyler deneyimleme vb. amaçlarla herhangi bir rekreasyon etkinliğine katılan bir bireydeki, etkinlik sonrasında veya sırasında oluşan yenilenme düzeyini tespit etmek ve dolayısıyla, ilgili etkinliğin bireyler üzerinde rekreatif anlamda performansını gözlenebilir k1lmaktır.

Hizmet kalitesi, bir işletmenin müşteri beklentilerini ne derecede karşılayabildiği ile ilgili bir kavram olarak tanımlanırken, yenilenme ise bireylerin gerçekleştirdikleri eylemlere karşı kişisel yenilenmiş olma tutumları ile alakalı bir kavramdır. Bu iki kavramın ortak özelliği ise; alınan bir hizmete, dahil olunan bir etkinliğe vb. durumlara yönelik, doğrudan bireylerin bakış açısına ve kişisel değerlendirmelerine dayalı kavramlar olmalarıdır. Bir birey yenilenmek, arınmak, mutlu olmak gibi amaçlarla bir etkinliğe katıldığında, etkinlik kapsamında bireye sunulan hizmetlerin de bu etkinliğin bir parçası olduğu göz önünde tutulduğunda, bu iki yapının ortak noktaları olduğunu görmek daha mümkün olacaktır. Ancak literatürde birbiriyle ortak noktaları bulunan bu iki yapı arasında nasıl bir ilişkinin bulunduğuyla ilgili önemli bir eksiklik göze çarpmaktadır. Örneğin yukarıda bahsi geçen bireyde katıldığı etkinlik sonrasında oluşan yenilenmenin düzeyi ile etkinlik kapsamında aldığı hizmetlerin kalitesi arasında bir ilişki var mıdır? Etkinlik sırasında alınan hizmetin kalitesi bireyin yenilenme düzeyini etkilemekte midir? Soruları akıllara gelmektedir.

Literatürde farklı müzelerde müze ziyaretçilerinin hizmet kalitesi algılarının ölçüldüğü, ayrıca hizmet kalitesi algılarının memnuniyete ve tavsiye etme niyetine etkisinin tespit edilmeye çalışıldığı birçok araştırma olmasına rağmen (Tokay, 2009; Hsieh, 2010; Radder ve Han, 2013; Wu ve Li, 2015; Hsieh vd., 2015; Aksu vd., 2017; Sert ve Karacaoğlu, 2018; Daskalaki vd., 2020; Saçl1 ve Kalaba, 2020) müze ziyaretçilerin, bir rekreasyon etkinliği olarak gerçekleştirdiği müze ziyaretleri sonrası yenilenme düzeylerinin ölçüldüğü herhangi bir araştırmaya rastlanmamıştır. Benzer şekilde "hizmet kalitesi" ile "yenilenme" kavramları arasındaki ilişkiyi ele alan herhangi bir araştırmaya da rastlanmamıştır. Bununla birlikte literatürde "hizmet kalitesi" ve "yenilenme" değişkenlerinin, farklı değişkenler ile etkileşim içinde/ilişkili olduğunu gösteren birçok araştırma mevcuttur (Tokay, 2009; Hsieh, 2010; Radder ve Han, 2013; Wu ve Li, 2015; Sever, Buzlu ve Y1ldız, 2015; Hsieh vd., 2015; Aksu, Saatc1 ve Güdü, 2017; Hsieh vd., 2018; Sert ve Karacaoğlu, 2018; Daskalaki vd., 2020). Literatürdeki bu araştırmalar "hizmet kalitesi" ve "yenilenme" değişkenlerinin de birbirleriyle ilişkisi olabileceği konusunda ampirik bir dayanak niteliğindedir. Bu nedenle literatürdeki bulgulara dayanarak, "hizmet kalitesi" ile "yenilenme" arasında da bir ilişki bulunabileceği öngörülmüştür. Bu öngörüye paralel olarak oluşan ve literatürdeki boşluğu doldurmak adına yapılan bu araştırmanın ana problemi: Hizmet kalitesi algıları ile yenilenme arasında bir ilişki var mıdır? Varsa ne yönde ve nasıl bir ilişki vardır? Şeklinde ortaya çıkmıştır. 
Araştırma kapsamında bu soruların cevapları aranmış ve öncelikle bireylerin hizmet kalitesi algıları ile yenilenme düzeyleri tespit edilerek, aralarında nasıl bir ilişki olduğu incelenmiştir. Ayrıca bireylerin hizmet kalitesi ile yenilenme düzeyleri arasındaki ilişkiden hareketle, hizmet kalitesi algılarının yenilenme değişkeni üzerindeki etkisi tespit edilmek istenmiştir. Araştırma neticesinde ortaya çıkan sonuçların literatüre önemli bir katkı sunacağı, ayrıca bireylerin müze ziyaretleri konusunda yeni bir bakış açısı oluşturacağı düşünülmektedir.

Kültür turizmi pazarındaki en büyük payı temsil eden müzeler (Hsieh, 2010:2), tüm dünyada turistlerin ilgi odağı durumundadır. Turizm ve Boş Zaman Eğitimi Derneği (ATLAS), müzelerin ve sanat galerilerinin kültür turizmi için en önemli çekim merkezleri olduğunu ve tüm kültürel ziyaretlerin yarısından fazlasını oluşturduğunu bildirmiştir (Richards, 2007:150; Hsieh, 2010:2). Müzelerin dünyadaki turizm hareketleri açısından bu denli önemli bir konumda olması sebebiyle, araştırmanın çalışma alanı olarak dünyanın en büyük mozaik koleksiyonuna sahip olan Hatay Arkeoloji Müzesi (T.C. Hatay Valiliğii, 2020) seçilmiştir.

\section{LITERATÜR}

Araştırmanın literatür kısmında hizmet kalitesi ve yenilenme değişkenlerinin farklı yapılarla olan etkileşimin/ilişkisini ele alan araştırmalar incelenmiştir. Bu araştırmanın çalışma alanı müze olarak belirlendiği için, çalışma kapsamında literatürde müzelerdeki hizmet kalitesini konu alan araştırmalara yer verilmiştir.

Sever, Buzlu ve Yıldız (2015) iki farklı örneklem grubu üzerinde yaptıkları araştırmada, ürün performansının "yenilenme" değişkeni üzerinde pozitif bir etkisi olduğu sonucuna ulaşmışlardır. Ayrıca araştırmada, yenilenmenin tavsiye niyeti ve tekrar ziyaret değişkenlerini de etkilediği sonucuna ulaşılmıştır. Tokay (2009), müze ziyaretçilerin hizmet kalitesi algıları ile memnuniyet ve tavsiye etme niyetleri arasında pozitif yönlü bir ilişkinin bulunduğunu tespit etmiştir. Hsieh (2010) yaptığı araştırmada, müze ziyaretçilerinin sadakati ile memnuniyet, hizmet kalitesi, değer algısı ve çekme motivasyonları arasında olumlu ilişkilerin olduğunu ortaya koymuştur. Radder ve Han (2013), müze ziyaretçilerinin hizmet kalitesi algılarının müşteri sadakati ve memnuniyeti üzerinde doğrudan ve dolaylı olarak etkili olduğu sonucuna ulaşmışlardır. Hsieh vd., (2015) yaptıkları araştırma sonucunda, müze ziyaretçilerinin hizmet kalitesi algılarının, sadakatleri üzerinde etkili olduğunu tespit etmişlerdir. Wu ve Li (2015), yaptıkları araştırmada, müze ziyaretçilerinin hizmet kalitesi algılarıyla memnuniyet düzeyleri arasında doğrudan bir ilişki olduğunu tespit etmişlerdir. Aksu, Saatcı ve Güdü (2017) araştırmalarında, müze ziyaretçilerinin hizmet kalitesi algılarıyla, tekrar ziyaret etme niyeti ve tavsiye etme davranışı arasında pozitif yönlü bir ilişki bulunduğu sonucuna ulaşmışlardır. Hsieh vd. (2018), müze ziyaretçilerinin içsel ve dişsal motivasyonları ve müze deneyimleri ile hizmet kalitesi algıları arasında anlamlı ve pozitif yönlü bir ilişki olduğunu tespit etmişlerdir. Sert ve Karacaoğlu (2018) müze ziyaretçileri üzerine yaptıkları araştırmalarında, ziyaretçilerin hizmet kalitesi algılarıyla memnuniyet düzeyleri ve tavsiye etme niyetleri arasında pozitif yönlü ve anlamlı bir ilişki bulunduğunu belirlemiştir. Daskalaki vd., (2020) ise yaptıkları araştırmada, müze ziyaretçilerinin hizmet kalitesi algıları, memnuniyet ve gelecekteki davranışları arasında güçlü bir ilişki bulunduğunu tespit etmişlerdir.

İlgili literatür incelendiğinde "yenilenme" değişkeninin ürün performansı, tekrar ziyaret ve tavsiye niyeti değişkenleri ile etkileşim halinde/ilişkili olduğu görülmektedir. Benzer şekilde literatürde bulunan ve müzelerdeki hizmet kalitesi algılarını konu alan araştırmalar incelendiğinde "hizmet kalitesi" değişkeninin memnuniyet, motivasyon, tavsiye etme niyeti, değer algısı, tekrar ziyaret etme ve ziyaretçi sadakati değişkenleri ile etkileşim halinde/ilişkili olduğu tekrarlı sınamalar ile ortaya konulmuştur. Literatürdeki bu bulgular hizmet kalitesi ve 
yenilenme değişkenlerinin farklı yapılar ile etkileşim içinde/ilişkili olduğunu göstermektedir. Literatürde yer alan bu bulgulara dayanarak "hizmet kalitesi" ile "yenilenme" değişkenlerinin de birbiriyle ilişkili yapılar olabileceği düşünülmektedir. Ancak literatürde hizmet kalitesi ve yenilenme değişkenlerinin birbirleriyle olan ilişkisini inceleyen herhangi bir araştırmaya rastlanmamıştır. Bu araştırmanın amacı literatürdeki bu açı̆̆ı kapatmaktır.

\section{YÖNTEM}

Bu araştırma sınayıcı (genelleyici, varsayımı sınayıcı) bir araştırmadır. Araştırma Hatay Arkeoloji Müzesi ziyaretçileri üzerinde, anket tekniği kullanılarak gerçekleştirilmiştir. Anket verileri tesadüfi olmayan kolayda örneklem yöntemine göre, müze ziyareti sonrası gönüllü olarak ankete katılmak isteyen müze ziyaretçilerine uygulanarak, 17.09.2020-16.11.2020 tarihleri arasında elde edilmiştir. Araştırmanın amaçlarına göre geliştirilen anket formu üç bölümden oluşmaktadır. Birinci bölümde katılımcıların kişisel bilgilerini tespit etmek amacıyla 11 ifade bulunmaktadır.

Anketin ikinci bölümü, Hatay Arkeoloji Müzesi ziyaretçilerinin hizmet kalitesi algılarını ölçen, 5 boyut (fiziksel özellikler, tüketilenler, empati, iletişim ve heveslilik) ve 25 ifadeden oluşmaktadır. Bu bölümdeki ifadeler Hsieh (2010) ve Hsieh, Park ve Hitchcock (2015)'un geliştirdiği, Sert ve Karacaoğlu'nun (2018) araştırmaları kapsamında Türkçeye çevirdiği MUSEQUAL ölçeği kullanılarak oluşturulmuştur. Hsieh (2010) ve Hsieh, Park ve Hitchcock (2015)'un geliştirdiği MUSEQUAL ölçeği 5 boyut ve 28 ifadeden oluşmaktadır. Ancak bu çalışmada, Hatay Arkeoloji Müzesi'nde uzman ve rehber bulunmadığı için, tıpkı Sert ve Karacaoğlu (2018) ve Akar'ın (2020) çalışmalarında olduğu gibi 3 ifade ölçekten çıkartılmıştır.

Anket formunun üçüncü ve son bölümü, Hatay Arkeoloji Müzesi ziyaretçilerinin, müze ziyaretleri sonrası yenilenme düzeylerini tespit etmek amacıyla, Koçak ve Eryılmaz (2018) tarafından geliştirilen yenilenme ölçeğinin, çalışmanın amaçları doğrultusunda müze ziyareti etkinliğine uyarlanmasıyla oluşturulan 4 ifadeden meydana gelmektedir.

Araştırmanın amaçları doğrultusunda geliştirilen anket formunun son hali, turizm alanında görev yapan akademisyenlere sunulmuş ve fikirleri alınmıştır. Akademisyenlerden gelen görüş ve öneriler dikkate alınarak, anket formunun nihai hali ortaya çıkmış, gerekli izinler ve belgeler alındıktan sonra veri toplama işlemine başlanmıştır. Ayrıca anket formuna dair etik kurul belgesi, Mersin Üniversitesinin 26/08/2020 tarihli etik kurul karar toplantısı sonrasında yazılı olarak alınmıştır (karar no-36).

Araştırmanın evreni 2020 yılında Hatay Arkeoloji Müzesini ziyaret eden bireylerden oluşmaktadır. Hatay Arkeoloji Müzesinin 2019 yılındaki ziyaretçi sayısı 221917 kişi olarak hesaplanmıştır (Kültür ve Turizm Bakanlığı, 2020). 2020 yılında ise yaşanan Covid-19 salgını sebebiyle tüm dünyadaki turizm hareketliliğindeki düşüş, müzenin belirli bir sürede tamamen kapalı olması ve geçici veya sürekli tedbirlerin bulunması sebepleriyle, müze ziyaretçi sayısının bir önceki yıla göre daha düşük bir seviyede olması öngörülmektir. Araştırma verilerinin bir kısmı yüz yüze anket tekniği ile toplanırken, bir kısmı ise Covid-19 salgınına bağlı olarak getirilen kısıtlamalar ve yüz yüze anket uygulamasının getirdiği riskler göz önüne alınarak çevrimiçi ortamda, müzeyi ziyaret ettiği tespit edilen ziyaretçilere ulaşılarak elde edilmiştir. Anketin çevrimiçi ortamda da gerçekleştirilmesi nedeniyle evren genişlemiş, evrenin tam sayısı belirlenemediğinden Kozak (2014) tarafından geliştirilen örneklem hesaplama cetveline göre \%95 güvenilirlik düzeyi ve evrenin heterojen varsayımı ile örneklem sayısı 384 olarak kabul edilmiştir. Anket uygulamasında bu sayıya ulaşılmaya ve aşılmaya çalışılarak örneklemin geçerliliği artırılmak istenmiştir. Bir kısmı yüz yüze bir kısmı çevrimiçi ortamda elde edilen 416 anket 
formundan eksik veya hatalı olan 12 adet anket formu çıkartılarak, araştırma kapsamında 404 anketten elde edilen veriler ile analizler gerçekleştirilmiştir.

Araştırma ölçeklerinde beşli Likert tekniği kullanılmıştır. Her ölçek ifadesi; (1) kesinlikle katılmiyorum, (2) katılmiyorum, (3) ne katılmiyorum ne katıliyorum, (4) katıliyorum, (5) kesinlikle katılıyorum seçeneklerinden oluşmaktadır. Araştırma kapsamında elde edilen veriler SPSS programı kullanılarak analiz edilmiştir. Elde edilen verilere araştırmanın amaçları doğrultusunda; geçerlilik ve güvenilirlik analizi, frekans analizi, faktör analizi, normallik testi, korelasyon ve regresyon analizleri uygulanmıştır.

\section{BULGULAR}

Hatay Arkeoloji Müzesi ziyaretçilerine uygulanan ankete katılmış olan bireylerin, anketin birinci bölümünde yer alan ve katılımcıların demografik bilgilerini içeren ifadelere verdikleri cevaplar Tablo 1'de gösterilmiştir.

Tablo 1. Katılımcıların Demografik Özellikleri

\begin{tabular}{|c|c|c|c|c|c|}
\hline Cinsiyet & $\mathrm{f}$ & $\%$ & Aylık Gelir & f & $\%$ \\
\hline Kadın & 211 & 52,2 & 2324 TL ve Alt1 & 130 & 32,2 \\
\hline Erkek & 193 & 47,8 & $2325-3000 \mathrm{TL}$ & 55 & 13,6 \\
\hline $\begin{array}{l}\text { Medeni } \\
\text { durumunuz }\end{array}$ & f & $\%$ & $3001-4000 \mathrm{TL}$ & 44 & 10,9 \\
\hline Evli & 147 & 36,4 & $4001-5000 \mathrm{TL}$ & 44 & 10,9 \\
\hline Bekar & 257 & 63,6 & 5001 TL ve Üzeri & 131 & 32,4 \\
\hline Yaş Aralığ & f & $\%$ & İkamet Ettiği Yer & $\mathrm{f}$ & $\%$ \\
\hline 20 Yaş ve Altı & 19 & 4,7 & Hatay & 125 & 30,9 \\
\hline $21-30$ Yaş & 199 & 49,3 & Diğer & 279 & 69,1 \\
\hline 31-40 Yaş & 113 & 28,0 & $\begin{array}{l}\text { Daha Önce Herhangi Bir } \\
\text { Müzeyi Ziyaret Etme } \\
\text { Durumu }\end{array}$ & f & $\%$ \\
\hline 41-50 Yaş & 36 & 8,9 & Evet & 399 & 98,8 \\
\hline 51 ve Üzeri & 37 & 9,2 & Hayır & 5 & 1,2 \\
\hline Eğitim Durumu & $\mathbf{f}$ & $\%$ & $\begin{array}{l}\text { Bu Müzeyi } \quad \text { Kaçıncı } \\
\text { Ziyaretiniz }\end{array}$ & f & $\%$ \\
\hline İlköğretim & 4 & 1,0 & İlk defa & 261 & 64,6 \\
\hline Lise & 42 & 10,4 & 2 & 89 & 22,0 \\
\hline Ön lisans/Lisans & 249 & 61,6 & 3 & 20 & 5,0 \\
\hline Lisansüstü & 109 & 27 & 4 ve üzeri & 34 & 8,4 \\
\hline Meslek Durumu & f & $\%$ & $\begin{array}{l}\text { Müzeyi Ziyaret } \\
\text { Durumu }\end{array}$ & f & $\%$ \\
\hline Özel Sektör & 66 & 16,3 & Bireysel Olarak & 338 & 83,7 \\
\hline Kamu Personeli & 89 & 22,0 & Tur Vasitasıly & 66 & 16,3 \\
\hline Serbest Meslek & 95 & 23,5 & Ziyarete Kimle Geldiniz & $f$ & $\%$ \\
\hline Öğrenci & 96 & 23,8 & Tek & 33 & 8,2 \\
\hline Ev hanımı & 3 & 0,7 & Ailemle & 166 & 41,1 \\
\hline Emekli & 24 & 5,9 & Arkadaşımla & 205 & 50,7 \\
\hline Diğer & 31 & 7,7 & TOPLAM & 404 & $\% 100$ \\
\hline
\end{tabular}


Tablo 1 incelendiğinde, araştırmaya dahil olan katılımcıların; \%52,2'sinin kadınlardan, $\% 63,6$ 'sının bekar bireylerden, \%49.3'ünün 21-30 yaş arası bireylerden, \%61,6'sının ön lisans/lisans seviyesinde eğitime sahip bireylerden, \%23,8'inin öğrenci bireylerden, \%32.4'ünün 5001 TL ve üzeri gelir seviyesine sahip bireylerden, \%69,1'inin Hatay dışında ikamet eden bireylerden, \%98,8'inin daha önce herhangi bir müzeyi ziyaret etmiş bireylerden, $\% 64,6$ 'sının Hatay Arkeoloji Müzesini ilk defa ziyaret eden bireylerden, \%83,7'sinin müze ziyaretini bireysel olarak gerçekleştiren bireylerden ve $\% 50,7^{\prime} \operatorname{sinin}$ müzeyi arkadaşları ile beraber ziyaret eden bireylerden oluştuğu görülmektedir.

Elde edilen verilerin faktör analizine uygun olup olmadığını görebilmek için, öncelikle verilerin faktör analitik modeline uygunluğuna ilişkin ölçütü ifade eden Kaiser Meyer Olkin (KMO) (Hair, Black, Babin ve Anderson, 2010) ve ifadelerin/değişkenlerin tutarlılığını ifade eden Bartlett's testi (Pett, Lackey ve Sullivan, 2003:77) değerlerine bakılmıştır. Elde edilen verilerin faktörlenebilmesi için KMO değerinin 0,5 üzerinde bir değer alması gerekmektedir (Hair vd., 2010). Hizmet kalitesi ölçeğinin faktör analizine uygunluğunu test etmek amacıyla yapılan KMO ve Bartlett Küresellik testi sonucunda, KMO değeri 0,847, Bartlett's değeri 0,000 olarak hesaplanmıştır. KMO değerinin 0,5 'den büyük olması, Bartlett's değerinin ise 0,001 'den düşük olması, elde edilen verilerin faktör analizine uygun olduğunu göstermektedir. 25 ifadeden oluşan MUSEQUAL ölçeğinin faktör analizi sonuçları Tablo 2' de görülmektedir.

Tablo 2. Hizmet Kalitesi Ölçeğinin Faktör Analizi Sonuçları

\begin{tabular}{|c|c|c|c|c|c|c|}
\hline Önermeler /İfadeler & $\begin{array}{l}\text { Faktör } 1 \\
\text { (Empati) }\end{array}$ & $\begin{array}{c}\text { Faktör } 2 \\
\text { (Tüketilenler) }\end{array}$ & \begin{tabular}{|c} 
Faktör 3 \\
(Fiziksel \\
Öz.)
\end{tabular} & $\begin{array}{c}\text { Faktör } 4 \\
\text { (Heveslilik) }\end{array}$ & $\begin{array}{c}\text { Faktör } 5 \\
\text { (Illetişim) }\end{array}$ & \begin{tabular}{|c} 
Toplam \\
Varyans \\
$\%$
\end{tabular} \\
\hline \begin{tabular}{|l|} 
Müzedeki ziyaretçi yoğunluğu \\
rahatsız etmemektedir. (HKÖ14)
\end{tabular} &, 879 & & & & & \multirow{13}{*}{62,019} \\
\hline $\begin{array}{l}\text { Müzedeki atmosfer sergilenen } \\
\text { eserlerle uyumludur. (HKÖ13) }\end{array}$ & ,858 & & & & & \\
\hline 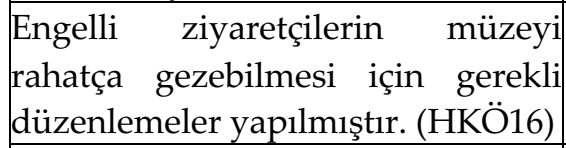 & 748, & & & & & \\
\hline $\begin{array}{l}\text { Müzedeki imkanlar çocuklar için } \\
\text { yeterlidir. (HKÖ17) }\end{array}$ & ,742 & & & & & \\
\hline $\begin{array}{l}\text { Müzedeki gürültü kabul edilebilir } \\
\text { düzeydedir. (HKÖ15) }\end{array}$ & ,737 & & & & & \\
\hline $\begin{array}{l}\text { Kafeterya personeli kaliteli hizmet } \\
\text { sunmaktadır. (HKÖ8) }\end{array}$ & & ,822 & & & & \\
\hline \begin{tabular}{|l|} 
Müzenin mağazasındaki ürün \\
çeşitliliği çoktur. (HKÖ10)
\end{tabular} & & 810 & & & & \\
\hline $\begin{array}{l}\text { Kafeterya kaliteli yiyecek/içecek } \\
\text { sunmaktadır. (HKÖ9) }\end{array}$ & & ,694 & & & & \\
\hline $\begin{array}{l}\text { Kafeteryada sunulan yiyecek/içecek } \\
\text { çeşitliliğ̆i çoktur. (HKÖ11) }\end{array}$ & & 680 & & & & \\
\hline $\begin{array}{l}\text { Müzedeki mağaza kaliteli ürünler } \\
\text { sunmaktadır. (HKÖ12) }\end{array}$ & & ,676 & & & & \\
\hline Müze temizdir. (HKÖ5) & & & ,799 & & & \\
\hline \begin{tabular}{|l} 
Müzede yeterli sayıda lavabo \\
vardır. (HKÖ2)
\end{tabular} & & & 679, & & & \\
\hline $\begin{array}{l}\text { Müzede sergilenen eserler çok } \\
\text { çeşitlidir. (HKÖ7) }\end{array}$ & & & 676, & & & \\
\hline
\end{tabular}




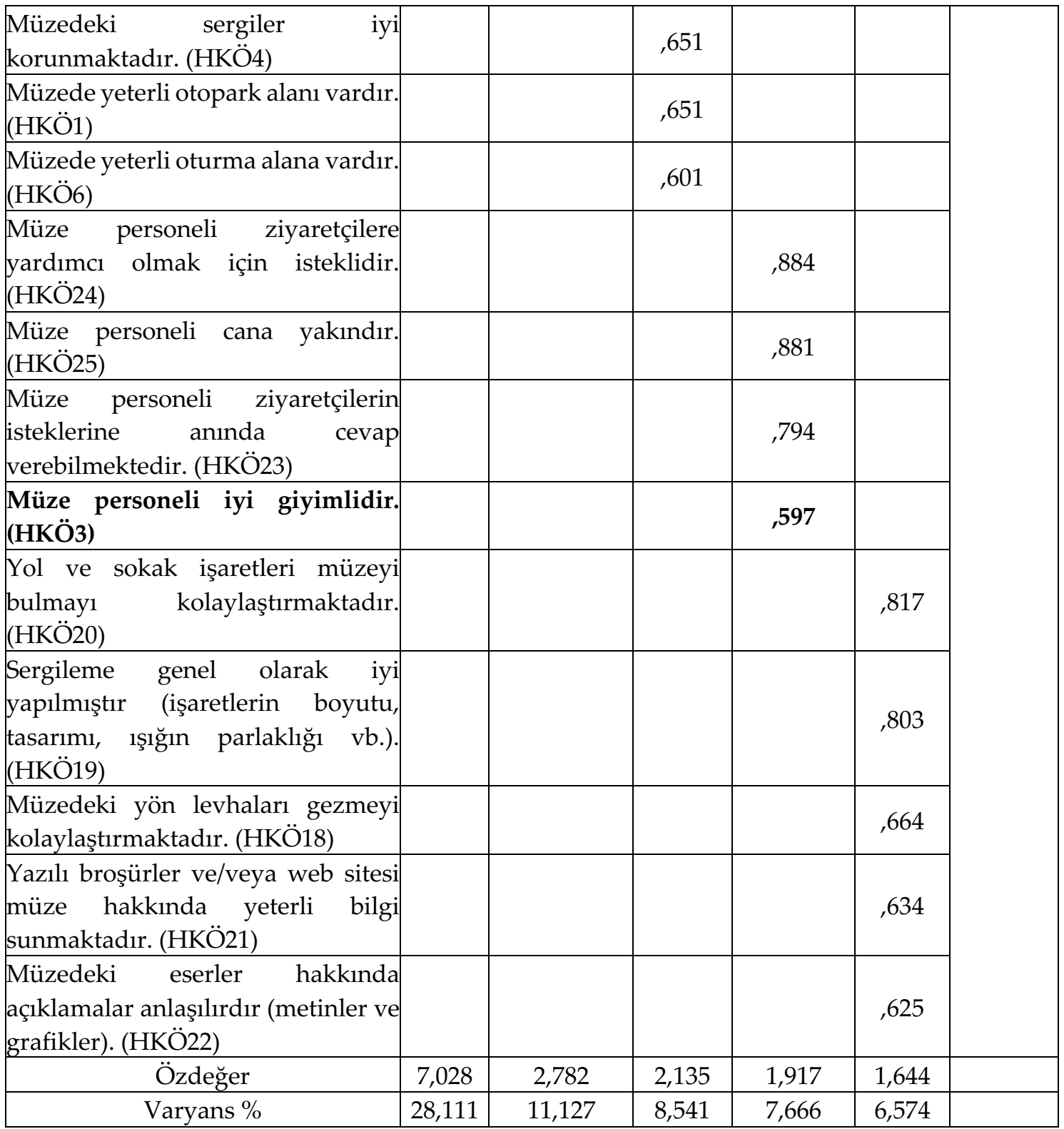

Not: HKÖ: Hizmet Kalitesi Önermesi

Faktör analizinde her faktör en az üç ifadeden oluşmalıdır. Her madde yalnızca bir faktör altında yer almalıdır. Eğer bir ifade birden fazla faktör altında bulunuyor veya eş kökenlilik değeri 0,400,50 değerinin altında kalıyorsa, sonraki analizlerde bu ifadeler ölçekten çıkartılarak analizler yapılmalıdır (Büyüköztürk, 2014:136; Sipahi, Yurtkoru ve Çinko, 2010:81). Tablo 2 incelendiğinde, tüm ifadelerin, 0,50'den yüksek bir eş kökenlilik değerine sahip olduğu görülmektedir.

Elde edilen verilere yapılan faktör analizi sonucunda, daha önceki araştırmalarda (Hsieh, 2010; Hsieh vd., 2015; Sert ve Karacaoğlu, 2018; Akar, 2020) fiziksel özellikler boyutunda (faktör 3) yer alan ve bu araştırmada da fiziksel özellikler boyutu altında faktörlenmesi beklenen HKÖ3 kodlu ifade, hizmet kalitesinin heveslilik boyutu (faktör 4) altında yer almıştır. Bu araştırmadaki örneklem grubunun farklı olması, HKÖ3 kodlu ifadenin 0,597'lik eş kökenlilik değerine sahip olması ve heveslilik boyutundaki diğer ifadelerle uyumluluk göstermesi nedenleriyle anket formundan çıkartılarak analizlere devam edilmesi mümkün olamayacağından, bu ifade heveslilik boyutuna ait bir ifade olarak kabul edilerek bundan sonra yapılan analizlerde bu 
boyuta dahil edilmiştir. Ayrıca faktör analizi sonucu ortaya çıkan bu durumu denetlemek ve desteklemek amacıyla, heveslilik boyutu altında faktörleşen ifadelerin birbiriyle olan ilişkisi incelenmiştir. Bu doğrultuda yapılan korelasyon analizi Tablo 3'te görülmektedir.

Tablo 2'de görüldüğü üzere, hizmet kalitesinin empati boyutu ölçekte ölçülmeye çalışılan özelliğin \%28,111'ini açıklamakta; hizmet kalitesinin tüketilenler boyutu ölçekte ölçülmeye çalışılan özelliğin \%11,127'sini açıklamakta; hizmet kalitesinin fiziksel özellikleri boyutu ölçekte ölçülmeye çalışılan özelliğin \%8,541'ini açılamakta; hizmet kalitesinin heveslilik boyutu ölçekte ölçülmeye çalışılan özelliğin \%7,666'sını açıklamakta; hizmet kalitesinin iletişim boyutu ise ölçekte ölçülmeye çalışılan özelliğin \%6,574'ünü açıklamaktadır. Genel anlamda hizmet kalitesi ölçeği (MUSEQUAL) ölçülmeye çalışılan özelliğin \%62,019'unu açılamaktadır. Bu sonuca göre hizmet kalitesi ölçeğinin yapı geçerliliğine sahip olduğu söylenebilir.

Tablo 3. Heveslilik Boyutu İfadeleri Arası Korelasyon Matrisi

\begin{tabular}{|c|c|c|c|c|}
\hline Faktör Maddeleri & $\begin{array}{c}\text { (HKÖ 3) } \\
\text { Müze } \\
\text { personeli iyi } \\
\text { giyimlidir. }\end{array}$ & $\begin{array}{c}\text { (HKÖ 23) Müze } \\
\text { personeli } \\
\text { ziyaretçi } \\
\text { isteklerine } \\
\text { anında cevap } \\
\text { verebilmektedir. }\end{array}$ & $\begin{array}{c}\text { (HKÖ24) Müze } \\
\text { personeli } \\
\text { ziyaretçilere } \\
\text { yardımc olmak } \\
\text { için isteklidir. }\end{array}$ & $\begin{array}{c}\text { (HKÖ25) } \\
\text { Müze } \\
\text { personeli } \\
\text { cana } \\
\text { yakıkndır. }\end{array}$ \\
\hline $\begin{array}{c}\text { (HKÖ 3) Müze personeli } \\
\text { iyi giyimlidir. }\end{array}$ & 1 & $\mathbf{0 , 4 5 2 ^ { * * }}$ & $\mathbf{0 , 5 2 9 * *}$ & $\mathbf{0 , 6 1 0 ^ { * * }}$ \\
\hline $\begin{array}{c}\text { (HKÖ 23) Müze } \\
\text { personeli ziyaretçi } \\
\text { isteklerine anında cevap } \\
\text { verebilmektedir. }\end{array}$ & 1 & $\mathbf{0 , 7 9 8 ^ { * * }}$ & $\mathbf{0 , 7 1 8 ^ { * * }}$ \\
\hline $\begin{array}{c}\text { (HKÖ24) Müze personeli } \\
\text { ziyaretçilere yardımc } \\
\text { olmak için isteklidir. }\end{array}$ & & & 1 & $\mathbf{0 , 8 4 0 ^ { * * }}$ \\
\hline $\begin{array}{c}\text { (HKÖ25) Müze personeli } \\
\text { cana yakındır. }\end{array}$ & & & & 1 \\
\hline
\end{tabular}

Tablo 3'te gösterilen değerlere bakılarak, heveslilik boyutu altında yer alan ifadelerin birebirleriyle olan korelasyon değerlerinin makul seviyede ve faktör analizinde ortaya çıkan sonucu destekler nitelikte olduğu söylenebilir. Bununla birlikte heveslilik boyutu altında yer alan tüm ifadelerin müze personelleriyle alakalı ifadeler olduğu dikkat çekmektedir. Bu araştırmadaki örneklem grubu, müze personelini bir bütün olarak değerlendirmiş ve bu sebeple de müze personelleriyle ilgili tüm ifadeler tek bir boyut altında toplanmış olabilir.

Yenilenme düzeyleri ölçeğinin faktör analizine uygunluğunu test etmek amacıyla yapılan KMO ve Bartlett Küresellik testi sonucunda, KMO değeri 0,654, Bartlett's değeri 0,000 olarak hesaplanmıştır. KMO değerinin 0,5'den büyük olması, Bartlett's değerinin ise 0,001'den düşük olması, elde edilen verilen faktör analizine uygun olduğunu göstermektedir. 4 ifadeden oluşan yenilenme düzeyleri ölçeğinin faktör analizi sonuçları Tablo 4 'te görülmektedir. 
Tablo 4. Yenilenme Düzeyleri Ölçeğinin Faktör Analizi Sonuçları

\begin{tabular}{|c|c|c|}
\hline İfadeler & Faktör 1 & $\begin{array}{c}\text { Toplam } \\
\text { Varyans } \\
(\%)\end{array}$ \\
\hline Müze ziyaretim sırasında yaptıklarımdan hoşlandım. (YÖ4) & 0,856 & \multirow{5}{*}{64,025} \\
\hline Müze ziyaretim sırasında farklı şeyler öğrendim. (YÖ3) & 0,809 & \\
\hline Müze ziyaretim sırasında farklı şeyler deneyimledim. (YÖ2) & 0,781 & \\
\hline Müze ziyaretim sırasında kendimi fiziksel olarak aktif hissettim. (YÖ1) & 0,751 & \\
\hline Özdeğer & 2,561 & \\
\hline
\end{tabular}

Not: YÖ: Yenilenme Önermesi

Tablo 4 incelendiğinde, 4 yenilenme düzeyi ifadesinin beklenildiği gibi tek faktör altında toplandığı görülmektedir. Ayrıca ifadelerin tümünün eş kökenlilik değerinin, kabul edilebilir seviye olan 0,50 ' den yüksek olduğu görülmektedir. 4 ifadeden oluşan yenilenme düzeyi bileşeni, bu ölçekte ölçülmeye çalışılan özelliğin \%64,025'ini açıklamaktadır. Bu sonuca göre yenilenme düzeyleri ölçeğinin yapı geçerliliğ̆ine sahip olduğu söylenebilir.

Ölçeklerin güvenilirliğini ölçerken en yaygın kullanılan yöntem Cronbach Alpha içsel tutarlılık katsayısıdır. Cronbach Alpha değeri 0 ile 1 arası bir değer alabilmektedir. Alınan değerin kabul edilebilir sayılması için en az 0,7 olması gerekmektedir (Coşkun, Altunışık, Bayraktaroğlu ve Yıldırım, 2015:126). Araştırma boyutlarına yapılan güvenilirlik analizinin sonucunda, hizmet kalitesi ölçeğinin genel (25 ifade) Cronbach's Alpha değeri 0,888 olarak hesaplanmıştır. Hizmet kalitesi boyutlarından olan fiziksel özellikler boyutu (6 ifade) Cronbach's Alpha değeri 0,763, tüketilenler boyutu (5 ifade) Cronbach's Alpha değeri 0,837, empati boyutu (5 ifade) Cronbach's Alpha değeri 0,873, iletişim boyutu ( 5 ifade) Cronbach's Alpha değeri 0,788, heveslilik boyutu (4 ifade) 0,886 olarak hesaplanmıştır. Yenilenme düzeyleri ölçeğinin (4 ifade) Cronbach's Alpha değeri ise 0,796 olarak hesaplanmıştır. Verilere yapılan güvenilirlik analizi sonucu, anket formunda yer alan ölçek ve boyutların tümünün Cronbach's Alpha değerinin, kabul edilebilir seviye olan 0,7'nin üzerinde çıkmış olması, verilerin güvenilir olduğunu göstermektedir.

Katılımcıların anket formunda yer alan ifadelere verdikleri cevaplara göre, her ifade için ayrı ayrı hesaplanan puan ortalamaları Tablo 5'de görülmektedir. Ayrıca Tablo 5'de her hizmet kalitesi boyutuna, genel hizmet kalitesi ve genel yenilenme düzeylerine yönelik oluşan puan ortalamalarına da yer verilmiştir.

Tablo 5 incelendiğinde, katılımcıların tüm hizmet kalitesi ifadelerine verdikleri cevaplara göre, genel hizmet kalitesi algılarının 3,91'lik bir ortalamaya sahip olduğu görülmektedir. Ayrıca katılımcıların yenilenme düzeyleri ölçeğindeki tüm ifadeleri verdikleri cevaplar incelendiğinde, ölçeğin 4,32'lik bir puan ortalamasına sahip olduğu görülmektedir. 
Tablo 5. Anket Formunda Yer Alan İfadelere Yönelik Tanımlayıcı İstatistikler

\begin{tabular}{|c|c|c|}
\hline HİZMET KALİTESİ (MUSEQUAL) Ölçeği İfadeleri ve Boyutları & Ortalama & $\begin{array}{c}\text { Standart } \\
\text { Sapma }\end{array}$ \\
\hline Fiziksel Özellikler Boyutu & 4,27 & 0,54763 \\
\hline Müzede yeterli otopark alanı vardır. & 4,01 & 1,080 \\
\hline Müzede yeterli sayıda lavabo vardır. & 4,24 & 0,699 \\
\hline Müzedeki sergiler iyi korunmaktadır. & 4,34 & 0,705 \\
\hline Müze temizdir. & 4,61 & 0,514 \\
\hline Müzede yeterli oturma alana vardır. & 3,88 & 1,082 \\
\hline Müzede sergilenen eserler çok çeşitlidir. & 4,57 & 0,587 \\
\hline Tüketilenler Boyutu & 3,80 & 0,73941 \\
\hline Kafeterya personeli kaliteli hizmet sunmaktadır. & 3,80 & 0,933 \\
\hline Kafeterya kaliteli yiyecek/içecek sunmaktadır. & 4,10 & 0,888 \\
\hline Müzenin mağazasındaki ürün çeşitliliği çoktur. & 3,55 & 1,077 \\
\hline Kafeteryada sunulan yiyecek/içecek çeşitliliği çoktur. & 3,54 & 0,977 \\
\hline Müzedeki mağaza kaliteli ürünler sunmaktadır. & 4,04 & 0,863 \\
\hline Empati Boyutu & 3,50 & 0,65879 \\
\hline Müzedeki atmosfer sergilenen eserlerle uyumludur. & 3,61 & 0,825 \\
\hline Müzedeki ziyaretçi yoğunluğu rahatsız etmemektedir. & 3,47 & 0,747 \\
\hline Müzedeki gürültü kabul edilebilir düzeydedir. & 3,55 & 0,881 \\
\hline $\begin{array}{l}\text { Engelli ziyaretçilerin müzeyi rahatça gezebilmesi için gerekli } \\
\text { düzenlemeler yapılmıştır. }\end{array}$ & 3,25 & 0,770 \\
\hline Müzedeki imkanlar çocuklar için yeterlidir. & 3,66 & 0,805 \\
\hline İletişim Boyutu & 4,05 & 0,65522 \\
\hline Müzedeki yön levhaları gezmeyi kolaylaştırmaktadır. & 4,28 & 0,831 \\
\hline $\begin{array}{l}\text { Sergileme genel olarak iyi yapılmıştır (işaretlerin boyutu, tasarımı, } \\
\text { 1şı̆̆ın parlaklığı vb.). }\end{array}$ & 4,32 & 0,857 \\
\hline Yol ve sokak işaretleri müzeyi bulmayı kolaylaştırmaktadır. & 4,09 & 0,979 \\
\hline $\begin{array}{l}\text { Yazılı broşürler ve/veya web sitesi müze hakkında yeterli bilgi } \\
\text { sunmaktadır. }\end{array}$ & 3,94 & 0,830 \\
\hline $\begin{array}{l}\text { Müzedeki eserler hakkında açıklamalar anlaşılırdır (metinler ve } \\
\text { grafikler). }\end{array}$ & 3,65 & 0,945 \\
\hline Heveslilik Boyutu & 3,85 & 0,72967 \\
\hline Müze personeli iyi giyimlidir. & 3,82 & 0,830 \\
\hline $\begin{array}{l}\text { Müze personeli ziyaretçilerin isteklerine anında cevap } \\
\text { verebilmektedir. }\end{array}$ & 3,86 & 0,819 \\
\hline Müze personeli ziyaretçilere yardımcı olmak için isteklidir. & 3,90 & 0,878 \\
\hline Müze personeli cana yakındır. & 3,82 & 0,853 \\
\hline Katılımcıların Genel Hizmet Kalitesi Algıları & 3,91 & 0,44711 \\
\hline \multicolumn{3}{|l|}{ YENİLENME ÖLÇEĞİ } \\
\hline Müze ziyaretim sırasında kendimi fiziksel olarak aktif hissettim. & 4,12 & 0,744 \\
\hline Müze ziyaretim sırasında farklı şeyler deneyimledim. & 4,17 & 0,800 \\
\hline Müze ziyaretim sırasında farklı şeyler öğrendim. & 4,48 & 0,534 \\
\hline Müze ziyaretim sırasında yaptıklarımdan hoşlandım. & 4,52 & 0,557 \\
\hline Katılımcıların Genel Yenilenme Düzeyleri Algıları & 4,32 & 0,52669 \\
\hline
\end{tabular}

Not: Ortalamalar alınırken katılımcılarm her ifade için işaretlediği "kesinlikle katılmıyorum" seçeneği 1 , "katılmiyorum" seçeneği 2, "ne katılmıyorum ne katıllyorum" seçeneği 3, "katıllyorum" seçeneği 4, "kesinlikle katıllyorum" seçeneği 5 puan olarak hesaplanmışıtır. 
George ve Mallery (2010), yapılan normallik testi sonucu ortaya çıkan çarpıklık (skewness) ve basıklık (kurtosis) değerlerinin +2.00 ile -2.00 arasından olması durumunda, verilerin normal dağılım gösterdiğinin varsayılabileceğini söylemiştir. Anket formunda bulunan ifadelere yapılan normallik testi sonucunda, çarpıklık ve basıklık değerleri sırasılyla -244 ve 1,235 olarak hesaplanmıştır. Ayrıca ölçümlerin sıklık dağılımları incelendiğinde ölçümlerin büyük bir bölümünün ortalamanın etrafında yoğunlaşması, ortalamadan uzaklaşıldıkça sıklıkların azalması nedeniyle veriler normal dağılım göstermektedir (Alpar, 2018:162).

Korelasyon (ilişki) katsayıları, değişkenler arasındaki ilişkinin kuvveti (derecesi) ve yönü hakkında bilgi veren ölçümlerdir. Korelasyon katsayıları -1 ile +1 arasında değerler almaktadır. 1 negatif tam ilişkiyi; +1 pozitif ilişkiyi belirtir (Alpar, 2018:403). Araştırmanın ana problemi doğrultusunda hizmet kalitesi değişkeni ile yenilenme değişkeni arasındaki ilişkiyi ortaya koymak adına yapılan korelasyon analizi sonuçları Tablo 6' da görülmektedir.

Tablo 6. Yapılar Arası Korelasyon Analizi Sonuçları

\begin{tabular}{|c|c|c|c|c|c|c|c|}
\hline & 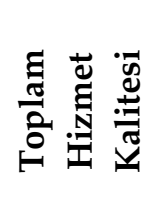 & 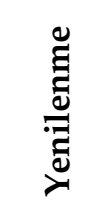 & 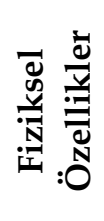 & 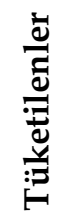 & 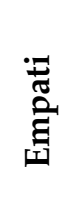 & 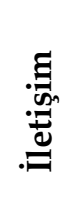 & 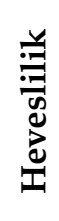 \\
\hline $\begin{array}{c}\text { Toplam Hizmet } \\
\text { Kalitesi } \\
\end{array}$ & 1 & & & & & & \\
\hline Yenilenme & $435^{* *}$ & 1 & & & & & \\
\hline Fiziksel Özellikler & 675 & $355^{* *}$ & 1 & & & & \\
\hline Tüketilenler & ,729 &, $348^{* *}$ & ,364 & 1 & & & \\
\hline Empati & 611 &, $125^{*}$ & ,240 & 280 & 1 & & \\
\hline İletişim & ,646 &, $330^{* *}$ & ,345 & ,310 & ,182 & 1 & \\
\hline Heveslilik & ,731 &, $311^{* *}$ & 341 & 451 & ,385 & ,365 & 1 \\
\hline
\end{tabular}

${ }^{* *} p<0,05$

Ölçme araçlarının sahip olduğu farklı geçerlilik türleri bulunmaktadır. Bu geçerlilik türlerinden bir tanesi de ayırt edici geçerliliktir. Ayırt edici geçerlilik, bir yapıyı ölçen ölçme aracı ile farklı yapıları ölçen ölçekler arasında zayıf/düşük ilişkilerin (düşük korelasyonun) olması anlamına gelmektedir (Coşkun vd., 2015:124). Tablo 6 incelendiğinde, hizmet kalitesini oluşturan boyutlar ile yenilenme düzeyleri arasındaki düşük ilişkiye (korelasyona) dayanarak, araştırmanın yapı geçerliliği dışında bir başka geçerlilik türü olan ayırt edici geçerliliğe de sahip olduğu söylenebilir.

Araştırmanın değişkenlerinin korelasyon katsayılarına (Tablo 6) bakıldığında, katılımcıların Hatay Arkeoloji Müzesi'nin hizmet kalitesine yönelik genel algılarıyla, yenilenme düzeyleri arasında orta düzeyde (Alpar, 2018:409), pozitif yönde ve istatistiksel olarak anlamlı ilişki olduğu görülmektedir $(\mathrm{r}=0,435 ; \mathrm{p}<0,05)$. Ayrıca katılımcıların Hatay Arkeoloji Müzesi hizmet kalitesinin; fiziksel özellikler, tüketilenler, iletişim ve heveslilik boyutlarına yönelik algılarıla, yenilenme düzeyleri arasında düşük (sırsıyla; $r=0,355 ; \mathrm{r}=0,348 ; \mathrm{r}=0,330 ; \mathrm{r}=0,311 ; \mathrm{p}<0,05$ ) empati boyutuna yönelik algilarıyla, yenilenme düzeyleri arasında önemsenmeyecek düzeyde düşük $(\mathrm{r}=0,125$; p<0,05) (Alpar, 2018:409), pozitif yönde ve istatistiksel olarak anlamlı ilişki vardır. Bu bulgulara bakılarak araştırmanın ana problemi olan "hizmet kalitesi algıları ile yenilenme değişkeni arasında bir ilişki var mıdır? Varsa ne yönde ve nasıl bir ilişki vardır? Sorularını, "hizmet kalitesi 
ile yenilenme değişkeni arasında, pozitif yönlü ve istatistiki açıdan anlamlı bir ilişki vardır" şeklinde yanıtlamak mümkündür.

Yapılan korelasyon analizi sonucunda hizmet kalitesi ile yenilenme değişkenleri arasındaki ilişki ortaya konulmuştur. İki yapı arasındaki bu ilişkiden hareketle, hizmet kalitesi algılarının yenilenme düzeyleri üzerinde nasıl bir etkisinin bulunduğu tespit edilmek istenmiştir. Hizmet kalitesi algılarını oluşturan boyutların yenilenme düzeyleri üzerindeki etkisini ortaya koymak adına yapılan çoklu doğrusal regresyon analizi sonuçları Tablo 7'de görülmektedir.

Tablo 7. Algılanan Hizmet Kalitesinin Yenilenme Düzeyleri Üzerindeki Etkisine İlişkin Çoklu Doğrusal Regresyon Analizi Sonuçları

\begin{tabular}{|c|c|c|c|c|c|}
\hline & $\begin{array}{c}\text { Standardize } \\
\text { Edilmemiş } \\
\text { Beta }\end{array}$ & $\begin{array}{c}\text { Standart } \\
\text { Sapma }\end{array}$ & $\mathbf{t}$ & $\mathbf{p}$ & Anlamlılık \\
\hline Sabit & 2,257 & 0,218 & 10,367 & $0,000^{*}$ & \multirow{6}{*}{$\begin{array}{l}\mathrm{F}=22,707 \\
\mathrm{P}=0,000^{*}\end{array}$} \\
\hline Fiziksel Özellikler & 0,194 & 0,048 & 4,043 & $0,000^{*}$ & \\
\hline Tüketilenler & 0,131 & 0,037 & 3,546 & $0,000^{*}$ & \\
\hline Empati & $-0,041$ & 0,039 & $-1,064$ & 0,288 & \\
\hline İletişim & 0.137 & 0,040 & 3,448 & $0,001^{*}$ & \\
\hline Heveslilik & 0,084 & 0,039 & 2,167 & $0,031^{*}$ & \\
\hline
\end{tabular}

${ }^{*} p<0,05 ;$ Düzeltilmiş $R^{2}=0,212$

Tablo 7'de görüldüğü üzere, katılımcıların Hatay Arkeoloji Müzesi'ne yönelik hizmet kalitesi algılamalarının, yenilenme düzeyleri üzerinde istatistiksel olarak anlamlı bir etkisi olup olmadığını ölçmek amacıyla yapılan çoklu doğrusal regresyon analizi sonucunda, p değeri 0,000 olarak hesaplanmış. Bu değer 0,05'ten küçük olduğu için, kurulan modelin anlamlı olduğu tespit edilmiştir. Katılımcıların Hatay Arkeoloji Müzesi'ne yönelik hizmet kalitesi algılamalarının yenilenme düzeyleri üzerinde istatistiksel olarak anlamlı bir etkisi olduğu görülmektedir. Görülen bu etki pozitif yöndedir. Hatay Arkeoloji Müzesi'ne yönelik hizmet kalitesi boyutları bağımsız değişkenleri, katılımcıların yenilenme düzeylerine yönelik algılamalarını \%21,2 olarak açılamaktadır $\left(\mathrm{R}^{2}=0,212\right)$.

Tablo 7'de görüldüğü üzere, hizmet kalitesi boyutlarından fiziksel özellikler boyutunun, yenilenme düzeyleri üzerinde istatistiksel olarak anlamlı bir etkisi olduğu tespit edilmiştir $(\mathrm{p}=0,000<0,05)$. Görülen bu etki pozitif yöndedir. Hizmet kalitesinin fiziksel özellikler boyutundaki 1 birimlik artış, yenilenme düzeyleri üzerinde 0,194'lük bir artışa neden olmaktadır (standardize edilmemiş beta $=0,194$ ).

Tablo 7'de görüldüğü üzere, hizmet kalitesi boyutlarından tüketilenler boyutunun, yenilenme düzeyleri üzerinde istatistiksel olarak anlamlı bir etkisi olduğu tespit edilmiştir ( $p=0,000<0,05)$. Görülen bu etki pozitif yöndedir. Hizmet kalitesinin tüketilenler boyutundaki 1 birimlik artış, yenilenme düzeyleri üzerinde 0,131'lik bir artışa neden olmaktadır (standardize edilmemiş beta $=0,131$ ).

Tablo 7'de görüldüğü üzere, hizmet kalitesi boyutlarından empati boyutunun, yenilenme düzeyleri üzerinde istatistiksel olarak anlamlı bir etkisinin olmadığı tespit edilmiştir $(\mathrm{p}=0,288>0,05)$. 
Tablo 7'de görüldügü üzere, hizmet kalitesi boyutlarından iletişim boyutunun, yenilenme düzeyleri üzerinde istatistiksel olarak anlamlı bir etkisi olduğu tespit edilmiştir $(p=0,001<0,05)$. Görülen bu etki pozitif yöndedir. Hizmet kalitesinin iletişim boyutundaki 1 birimlik artış, yenilenme düzeyleri üzerinde $0,137^{\prime}$ lik bir artışa neden olmaktadır (standardize edilmemiş beta $=0,137)$.

Tablo 7'de görüldüğü üzere, hizmet kalitesi boyutlarından heveslilik boyutunun, yenilenme düzeyleri üzerinde istatistiksel olarak anlamlı bir etkisi olduğu tespit edilmiştir $(p=0,031<0,05)$. Görülen bu etki pozitif yöndedir. Hizmet kalitesinin heveslilik boyutundaki 1 birimlik artış, yenilenme düzeyleri üzerinde $0,084^{\prime} l u ̈ k$ bir artışa neden olmaktadır (standardize edilmemiş beta $=0,084$ )

\section{TARTIŞMA, SONUÇ ve ÖNERI}

Destinasyonların tarihsel ve kültürel birikimlerinin sergilendiği en önemli mekanlardan biri olan müzeler, tarihsel ve kültürel değerlerin geleceğe aktarılması konusunda oldukça önemli bir yere sahiptir. Müzelerin sürdürülebilirliklerini sağlayabilmeleri için ziyaretçilerinin memnuniyet düzeyleri, hizmet kalitesi algıları, müzeye geliş nedenleri, yenilenme düzeyleri, müzeden istek ve beklentileri gibi konuları, doğru bir şekilde tespit ve analiz etmesi gerekmektedir. Bu araştırmanın ana amacı, bireylerin hizmet kalitesi algıları ile yenilenme düzeleri arasındaki ilişkiyi incelemektir. $\mathrm{Bu}$ amaç doğrultusunda çalışma alanı olarak oldukça geniş hizmet alanlarına ve çeşitliliğine sahip olan ve mozaik sergi koleksiyonu bakımından dünya birincisi konumunda bulunan Hatay Arkeoloji Müzesi (T.C. Hatay Valiliği, 2020) seçilmiştir.

Araştırmanın amaçları doğrultusunda elde edilen verilere yapılan faktör analizi sonucunda, literatürde bulunan çalışmalarda (Hsieh, 2010; Hsieh vd., 2015, Sert ve Karacaoğlu, 2018; Akar, 2020) hizmet kalitesinin fiziksel özellikleri boyutu altında yer alan ve bu araştırmada da fiziksel özellikler boyutu altında faktörlenmesi beklenen hizmet kalitesi ölçeğinin üçüncü önermesi (müze personeli iyi giyimlidir), hizmet kalitesinin heveslilik boyutu altında yer almıştır. İlgili ifadenin 0,597'lik eş kökenlilik değerine sahip olması ve yapılan ilişki testi sonucunda heveslilik boyutundaki diğer ifadelerle uyumluluk göstermesi nedeniyle, bu ifade hizmet kalitesinin heveslilik boyutuna dahil edilerek analizler gerçekleştirilmiştir. Heveslilik boyutu altında yer alan diğer ifadeler incelendiğinde, bu ifadelerin tümünün müze personeli ile ilgili ifadeler olduğu ve müze personelleriyle ilgili tüm ifadelerin yalnızca heveslilik boyutu altında yer aldığ 1 fark edilmektedir. Bu sonucu göre, bu araştırmadaki örneklem grubunun müze personellerinin diş görünümlerini, bilgi ve becerilerini vb. özelliklerini ayırt etmeksizin, personelleri bir bütün olarak değerlendirmiş olabileceği düşünülmektedir. Bu doğrultuda ölçek farklı örneklem grupları üzerinde benzer sonuçları verebilir, farklı örneklem grupları da bu araştırmada elde edilen sonuca benzer şekilde müze personellerini bir bütün olarak değerlendirebilir. Dolayısiyla bundan sonraki yapılacak araştırmalarda uygulanan faktör analizi neticesinde ortaya çıkan sonuçlar, bu araştırmadaki faktör analizi sonuçları ile karşılaştırılarak, bu araştırmada elde edilen faktör analizi sonucu test edilebilir.

Araştırmaya dahil olan katılımcıların demografik özellikleri incelendiğinde yarısından çok daha fazlası olan \%88,6'sının üniversite düzeyinde eğitim almış bireylerden oluştuğu görülmektedir. Bu sonuç Yücelt (2000), Hsieh (2010), Yılmaz (2011), Cheng ve Wan (2012), Markovic vd. (2013), Hsieh vd. (2015), Putra (2016), Gündoğan vd. (2017), Aksu vd. (2017), Sert ve Karacaoğlu (2018), Kurulgan ve Bayram (2018), Ali vd. (2019), Saçlı ve Kalaba (2020), Daskalaki vd., (2020) ve Akar (2020) çalışmalarıyla paralellik göstermektedir. Bununla birlikte katılımcıların yalnızca \%8,2'lik kısmı müze ziyaretlerini tek başlarına gerçekleştirmiştir. Elde edilen bu bulgulara göre, bireylerin 
eğitim durumlarıyla, müze ziyareti gerçekleştirme durumları arasında bir ilişki olduğu, üniversite düzeyinde eğitim almış bireylerin müze ziyareti faaliyetine daha fazla katılım gösterdiği ve bireylerin müze ziyaretleri faaliyetini arkadaşlarıyla veya aileleriyle gerçekleştirmeyi tercih ettikleri söylenebilir. Benzer şekilde müzelerde yapılan araştırmalar, sosyo-ekonomik sınıf ve eğitimin, müze ziyaret alışkanlığı ile güçlü bir şekilde ilişkili olduğunu ortaya koymaktadır (Falk, 1998; Kawashima, 1999; Yucelt, 2000; Harrison ve Shaw, 2004; Aktaran: Hsieh vd., 2015).

Araştırma kapsamında elde edilen verilere yapılan faktör analizine göre "fiziksel özellikler", "tüketilenler", "empati", "iletişim" ve "heveslilik" olmak üzere 5 ana boyuttan oluşan hizmet kalitesi ölçeği, Frochot ve Hughes (2000), Allen (2001), Hsieh (2010), Cheng ve Wan (2012), Hsieh vd. (2015), Putra (2016), Sert ve Karacaoğlu (2018), Hsieh vd. (2018), Ali vd., (2019) ve Akar (2020) tarafından tarihi binalar ve müzelerdeki hizmet kalitesiyle ilgili yapılan araştırmalarla benzerlik göstermektedir. Buna göre müzelerin bu araştırmada da kullanılan ve 5 boyuttan oluşan hizmet kalitesi ölçeğini kullanarak ziyaretçilerinin hizmet kalitesi algılarını belirli aralıklarla, doğru ve verimli bir şekilde ölçebileceği söylenebilir.

Katılımcıların verdikleri cevaplara göre, hizmet kalitesi boyutlarından fiziksel özellikler boyutunun, 4,27'lik puan ortalaması ile hizmet kalitesi boyutları arasında en yüksek algı ortalamasına sahip boyut olduğu tespit edilmiştir. Bu sonuç Cheng ve Wan (2012), Hsieh vd. (2015), Putra (2016), Güneş vd., (2019) ve Akar (2020) çalışmalarıyla benzerlik göstermektedir. Katılımcların verdikleri cevaplara göre en olumlu algılara sahip diğer boyular ise sirasiyla iletişim $(4,05)$, heveslilik $(3,85)$, tüketilenler $(3,80)$ ve empati $(3,50)$ boyutları şeklindedir. Katılımcıların tüm hizmet kalitesi ifadelerine verdikleri cevaplara göre, genel hizmet kalitesi algıları 3,91'lik bir ortalama oluşturmuştur. Oluşan bu ortalamanın anket formunda yer alan ve 4 puan olarak değerlendirilen "katılıyorum" seçeneğine oldukça yaklaştı̆̆ göz önüne alınarak, ziyaretçilerin Hatay Arkeoloji Müzesi'ne yönelik genel hizmet kalitesi algılarının yüksek seviyede olduğu söylenebilir.

Katılımcıların verdikleri cevaplara göre, yenilenme düzeyleri ölçeğindeki "müze ziyaretim sırasında yaptıklarımdan hoşlandım" ifadesi 4,52'lik puan ortalamasına sahip olarak, yenilenme düzeyleri ölçeğinin ifadeleri arasında en yüksek ortalamaya sahip ifade konumundadır. Elde edilen bu bulgu Sever, Buzlu ve Yıldız'ın (2015) festival katılımcıları üzerinde yaptıkları araştırmayla benzerlik göstermektedir. Ziyaretçilerin yenilenme düzeyleri ölçeğindeki tüm ifadelere verdikleri cevaplar incelendiğinde, ölçeğin 4,32'lik bir puan ortalamasına sahip olduğu görülmektedir. Ortaya çıkan bu ortalamanın, Sever, Buzlu ve Yıldız'ın (2015) festival katılımcılarının yenilenme düzeylerini ölçtügü çalışmada ortaya çıkan 4,06'lık ortalamadan daha yüksek olduğu, dolayısıyla bireylerde Hatay Arkeoloji Müzesi ziyareti sonrasında oluşan yenilenme düzeyinin Mersin Narenciye Festivali'ne katılımları sonrasında oluşan yenilenme düzeylerine kıyasla daha yüksek seviyede olduğu tespit edilmiştir. Oluşan cevap ortalamasının $(4,32)$ anket formunda yer alan ve 4 puan olarak değerlendirilen "katıllyorum" seçeneğini geçmesi ve 5 puan olarak değerlendirilen "kesinlikle katılıyorum" seçeneğine doğru yaklaşması göz önünde bulundurularak, ziyaretçilerin Hatay Arkeoloji Müzesi ziyareti sonrası yenilenme düzeylerinin oldukça yüksek seviyede olduğu söylenebilir. Elde edilen bu bulgulara dayanarak bir rekreasyon etkinliği olan müze ziyaretinin, bireylerin yenilenme düzeyleri üzerinde olumlu bir etkiye sahip olduğu ve müze ziyaretleri sayesinde bireylerin kendilerini yüksek seviyede "yenileyebildiği" söylenebilir.

Araştırmanın ana amacı doğrultusunda uygulanan korelasyon analizi neticesinde, müze ziyaretçilerinin hizmet kalitesi algılarıyla yenilenme düzeyleri arasında orta düzeyde ve istatistiksel açıdan anlamlı ilişki olduğu sonucuna ulaşılmıştır. Bu sonuca göre araştırmanın ana problemi/sorusu olan "hizmet kalitesi ile yenilenme değişkeni arasında bir ilişki var mıdır?" 
sorusunu da, "hizmet kalitesi ile yenilenme değişkeni arasında, orta düzeyde, pozitif yönlü ve istatistiki açıdan anlamlı bir ilişki vardır" şeklinde yanıtlamak mümkündür. Ayrıca katılımcıların yenilenme düzeyleri ile hizmet kalitesinin fiziksel özellikler, tüketilenler, iletişim ve heveslilik boyutları arasındaki ilişki düşük düzeydeyken, yenilenme düzeyleri ile hizmet kalitesinin empati boyutu arasındaki ilişkinin önemsenmeyecek derecede düşük olduğu tespit edilmiştir.

Yapılan korelasyon analizi sonucunda, ziyaretçilerin hizmet kalitesi algıları ile yenilenme düzeyleri arasındaki ilişki ortaya konmuştur. Bu ilişkiden hareketle, katılımcıların hizmet kalitesi algılarının yenilenme düzeyleri üzerindeki etkisini tespit etmek amacıyla yapılan çoklu regresyon analizi sonucunda, müze ziyaretçilerinin hizmet kalitesi algılarının yenilenme düzeyleri üzerinde istatistiksel açıdan anlamlı bir etkisi olduğu sonucuna ulaşılmıştır. Müze ziyaretçilerinin hizmet kalitesi algılarını oluşturan fiziksel özellikler, tüketilenler, iletişim ve heveslilik boyutlarının, ziyaretçilerin yenilenme düzeyleri üzerinde istatistiksel olarak anlamlı bir etkisinin olduğu tespit edilmiştir. Yenilenme düzeyleri üzerinde en büyük etkiye sahip hizmet kalitesi boyutları sırasıyla; fiziksel özellikler, iletişim, tüketilenler ve heveslilik boyutları olarak tespit edilmiştir. Hizmet kalitesi boyutlarından empati boyutunun ise müze ziyaretçilerinin yenilenme düzeyleri üzerinde istatistiksel olarak anlamlı bir etkisinin olmadığı sonucuna ulaşılmıştır. Daha önce yapılan korelasyon analizi sonucunda da empati boyutuyla yenilenme düzeyleri arasında önemsenmeyecek kadar düşük bir ilişki olduğu sonucuna ulaşılmıştı. Bu bulgulara göre empati boyutunda yer alan "ziyaretçi yoğunluğu", "müzedeki gürültü", "müze atmosferi", "engelli ziyaretçiler ve çocuklar için sunulan imkanlar" a yönelik algıların, müze ziyaretçilerinin yenilenme düzeyleri üzerinde anlamlı bir etkisinin olmadığı ve bu ifadelerin yenilenme düzeyleriyle önemsenmeyecek düzeyde ilişkili olduğu söylenebilir. Bu doğrultuda ziyaretçilerin yenilenme düzeylerine önem veren müze yönetimlerinin, empati boyutunun altında yer alan ifadelerden çok diğer boyutların altında yer alan ifadelere ve hizmet alanlarına odaklanması, ziyaretçilerin yenilenme düzeylerinin arttırılması ve daha olumlu sonuçlara ulaşılması açısından doğru bir yaklaşım olabilir.

Araştırma kapsamında elde edilen bulgulara dayanarak, müzelerin potansiyel ziyaretçilerine “müze ziyareti gerçekleştiren bireyler, ziyaretleri sonrası kendilerini yenilenmiş hissederek müze ziyaretlerinden yenilenme, arınma, mutlu olma, farklı şeyler öğrenme gibi çeşitli faydalar sağlayabilir" şeklinde vaatlerde bulunması gerçekçi bir yaklaşım olacaktır. Ancak müzelerin kendilerini potansiyel ziyaretçilere karşı bu şekilde pazarlarken, araştırma bulgularını dikkate alması, bireylerin hizmet kalitesi algılarının yenilenme düzeyleri ile ilişki içerisinde olduğunu, paralel bir eğilim gösterdiğini ve etkilediğini de göz önünde bulundurması, bu sebeplerle sunulan hizmetlerin kalitesinden ödün vermemesi gerekmektedir.

Hatay Arkeoloji Müzesi yönetimine sunulan öneriler aşağıda sıralanmıştır.

- Müzede rehberlik hizmeti bulunmadığı için MUSEQUAL ölçeğinde yer alan 3 ifade ölçekten çıartılmıştır. Müze, bu konudaki eksikliği gidermek ve ziyaretçilerine rehberlik hizmeti sunmak için, İskenderun Teknik Üniversitesi'nin turizm fakültesine bağlı seyahat işletmeciliği ve turist rehberliği bölümüyle çeşitli şekillerde işbirliğine gidebilir.

- Ziyaretçilerin yenilenme düzeyleri algılarını hizmet kalitesi dışında nelerin etkilediği/nelerle ilişkili olduğu tespit edilerek, yenilenme düzeyleri algıları yükseltilebilir.

- Müze yönetimi tarafından ziyaretçilerin yenilenme düzeylerine önem verilmeli ve ziyaretçilerin müze ziyaretleri sonrasında kendilerini "yenileyebiliyor" olma durumları, daha fazla ziyaretçi çekebilmek adına yeni bir pazarlama aracı olarak kullanılmalıdır.

Gelecek çalışmalara yönelik olarak; 
- Hizmet kalitesinin belirli dönemlerde aynı veya farklı yöntemler ile ölçümlenerek bu araştırmanın sonuçlarıyla karşılaştırılması,

- Müzede yapılan yeniliklerin ve hizmet kalitesi iyileştirmelerinin ziyaretçilerin algılarına göre hizmet kalitesine yansımalarını ve geri bildirimlerinin ölçümlenmesi,

- Müze ziyareti veya farklı rekreasyon etkinlikleri katılımcılarının yenilenme düzeyleri ölçülerek, bu araştırmada elde edilen sonuçlarla karşılaştırılması,

- Müzelerde veya farklı hizmet alanlarında hizmet kalitesinin yenilenme düzeyine, yenilenme düzeyinin tekrar ziyaret etme niyeti ve tavsiye etme niyeti üzerine etkisi ve/veya yapılar arasındaki ilişkinin incelenmesi gibi çalışmalar gerçekleştirilmesi,

- Bireylerin yenilenme düzeyleri ile hizmet kalitesi dışındaki başka değişkenlerle arasındaki ilişkilerin incelenmesi önerilmektedir.

\section{KAYNAKÇA}

Akar, A. (2020). Müzelerde Algılanan Hizmet Kalitesi: İstanbul'daki Özel Çağdaş Sanat Müzeleri Örneği. Yüksek Lisans Tezi, İstanbul Üniversitesi Sosyal Bilimler Enstitüsü, İstanbul.

Aksu, M., Saatcl, G. ve Demirbulat, G. Ö. (2017). Çanakkale Arkeoloji Müzesi'ni Ziyaret Eden Yerli Turistlerin Hizmet Kalitesi Algilarının Belirlenmesi. Eurasian Academy of Sciences Social Science Journal (Internatiol Refereed \& Indexed), (Özel Sayl), 389-401.

Ali, Z. M., Zawawi, R., Myeda, N. E. and Mohamad, N. (2019). Adaptive Reuse of Historical Buildings: Service Quality Measurement of Kuala Lumpur Museums. International Journal of Building Pathology and Adaptation, 37(1), 54-68.

Allen, E. (2001). Can The Neglect of Defining and Evaluating Service Quality in Museums Be Effectively Addressed by SERVQUAL. (Unpublished MA Thesis). The Nottingham Trent University.

Alpar, R. (2018). Uygulamalı İstatistik ve Geçerlilik ve Güvenilirlik (Beşinci Baskı). Detay Yayıncılık, Ankara.

Berry, L. L., Parasuraman, A. and Zeithaml, V. A. (1988). The Service-Quality Puzzle. Business Horizons, 31(5), 35-43.

Büyüköztürk, Ş. (2014). Sosyal Bilimler İçin Veri Analizi El Kitabı (24.Baskı). Pegem Akademi, Ankara.

Cheng, I. M. and Wan, Y. K. P. (2012). Service Quality of Macao Museums. Journal of Quality Assurance in Hospitality \& Tourism, 13(1), 37-60.

Coşkun, R., Altunışık, R., Bayraktaroğlu, S. ve Yıldırım, E. (2015). Sosyal Bilimlerde Araştırma Yöntemleri, (8. Bask1). Sakarya Kitabevi, Sakarya.

Cronin Jr, J. J. and Taylor, S. A. (1994). SERVPERF Versus SERVQUAL: Reconciling PerformanceBased Aand Perceptions-Minus-Expectations Measurement of Service Quality. Journal of Marketing, 58(1), 125-131.Crosby, P. B. (1979). Quality is Free: The Art of Making Quality Certain (Vol. 94). New York: Mcgraw-Hill.

Cronin Jr, J. J. and Taylor, S. A. (1992). Measuring Service Quality: A Reexamination and Extension. Journal of Marketing, 56(3), 55-68. 
Daskalaki, V. V., Voutsa, M. C., Boutsouki, C. and Hatzithomas, L. (2020). Service Quality, Visitor Satisfaction and Future Behavior in The Museum Sector. Journal of Tourism, Heritage \& Services Marketing (JTHSM), 6(1), 3-8.

Falk, J. (1998). Visitors: Who does, who doesn't and why. Museum News, 77(2), 38-43.

Frochot, I. and Hughes, H. (2000). HISTOQUAL: The Development of a Historic Houses Assessment Scale. Tourism Management, 21(2), 157-167.

George, D. and Mallery, M. (2010). SPSS for Windows Step by Step: A Simple Guide and Reference, 17.0 update (10a ed.) Boston: Pearson

Gündoğan, H. R., Bulut E., Alkan B. N., Giritlioğlu İ. ve Saçlı, Ç. (2017). Zeugma Mozaik Müzesini Ziyaret Eden Yerli Ziyaretçilerin Hizmet Kalitesi Algılamalarının Belirlenmesi. 18. Ulusal Turizm Kongresi "Kültür Turizmi" Bildiri Kitabı Detay Yayıncılık, Ankara, 990-1005.

Güneş, E., Pekerşen, Y., Alagöz, G. ve Sivrikaya, K. K. (2019). Müze Ziyaretçilerinin Hizmet Kalitesine Yönelik Algılamaları: Mevlana Müzesi Örneği. Akademik Araştırmalar ve Çalş̧malar Dergisi (AKAD), 11(21), 591-612.

Hair, J. F., Black, W. C., Babin, B. J. and Anderson, R. E. (2010). Multivariate Data Analysis a Global Perspective. New Jersey: Pearson.

Harrison, P. and Shaw, R. (2004). Consumer Satisfaction and Post-Purchase Intentions: An Exploratory Study of Museum Visitors. International Journal of Arts Management, 6(2), 23-32.

Hatay Valiliği, (2020). http://www.hatay.gov.tr/arkeoloji-muzesi (Erişim Tarihi: 15.10.2020).

Hsieh, C. M. (2010). Roles of Motivations, Past Experience, Perceptions of Service Quality, Value and Satisfaction in Museum Visitors' Loyalty. Michigan State University.

Hsieh, C. M., Chen, T. P., Hsieh, C. J. and Tsai, B. K. (2018). Moderating Effect of Membership Status on the Quality-Value-Loyalty Chain at Museums. Social Behavior and Personality: An İnternational Journal, 46(1), 107-126.

Hsieh, C. M., Park, S. H. and Hitchcock, M. (2015). Examining The Relationships Among Motivation, Service Quality and Loyalty: The Case of the National Museum of Natural Science. Asia Pacific Journal of Tourism Research, 20(Sup1), 1505-1526.

Karaküçük, S. (2014). Rekreasyon: Boş Zamanları Değerlendirme (Altıncı Baskı). Gazi Kitabevi, Ankara.

Kawashima, N. (1999). Knowing The Public. A Review of Museum Marketing Literature and Research. Museum Management and Curatorship, 17(1), 21-39.

Koçak, G. N. ve Eryılmaz, G. (2018). Rekreasyon Araştırmaları İçin Temel Bir Araştırma Yapısı ve Ölçek Önerisi. Gaziantep Üniversitesi Spor Bilimleri Dergisi, 3(2), 61-84.

Kozak, M. (2014). Bilimsel Araştırma: Tasarım, Yazım ve Yayım Teknikleri (Birinci Baskı). Detay Yayıncilık, Ankara.

Kurulgan, M. ve Bayram, F. (2018). Müzelerde Algilanan Hizmet Kalitesi Boyutları: Anadolu Üniversitesi Eğitim Karikatürleri Müzesi'nde Bir İnceleme. Türkiye Sosyal Araşttrmalar Dergisi, 22(2), 375-410.

Kültür ve Turizm Bakanlığı, (2020). http://www.dosim.gov.tr/assets/documents/2019ZIYARETCI-WEB-SITESI.pdf (Erişim Tarihi: 15.10.2020). 
Markovic, S., Raspor Jankovic, S. and Komšić, J. (2013). Museum Service Quality Measurement Using the Histoqual Model. 2nd International Scientific Conference Tourism in South East Europe.

Parasuraman, A., Zeithaml, V. A. and Berry, L. L. (1985). A Conceptual Model of Service Quality and Its İmplications for Future Research. Journal of Marketing, 49(4), 41-50.

Parasuraman, A., Zeithaml, V. A. and Berry, L. L. (1988). SERVQUAL: A Multiple-İtem Scale for Measuring Consumer Perc. Journal Of Retailing, 64(1), 12-40.

Pett, M. A., Lackey, N. R. and Sullivan J. J. (2003). Making Sense of Factor Analysis: The Use of Factor Analysis for Instrument Development in Health Care Research. SAGE Publications.

Putra, F. (2016). Implementation of HISTOQUAL Model to Measure Visitors' Expectations and Perceptions in Museum Geology Bandung. In Asia Tourism Forum 2016-The 12th Biennial Conference of Hospitality and Tourism Industry in Asia. Atlantis Press.

Radder, L. and Han, X. (2013). Perceived Quality, Visitor Satisfaction and Conative Loyalty in South African Heritage Museums. International Business \& Economics Research Journal (IBER), 12(10), 1261-1272.

Richards, G. (Ed.). (2007). Cultural Tourism: Global and Local Perspectives. Psychology Press.

Saçlı, Ç. ve Kalaba, B. (2020). Müze Ziyaretçilerinin Hizmet Kalitesi Algıları: Hatay Arkeoloji Müzesi Örneği. 4. Uluslararası Mersin Sempozyumu Bildiri Kitabı, Mersin, 280-311

Sert, Ü. A. N. ve Karacaoğlu, S. (2018). Müzelerdeki Hizmet Kalitesinin Memnuniyet Algısı ve Tavsiye Etme Niyeti Üzerindeki Etkisi: Anadolu Medeniyetleri Müzesi Örneği. Afyon Kocatepe University Journal of Social Sciences, 20(2), 103-122.

Sever, G. N., Buzlu, M. Ö. ve Yıldız, G. (2015). Tüketim Sonrası Davranış Sürecinde "Yenilenme" Etkisinin Analizi. Turizm ve Araştırma Dergisi, 4 (2).

Sipahi B., Yurtkoru S., ve Çinko M. (2010). Sosyal bilimlerde SPSS'le veri analizi. Beta Yayınları, İstanbul.

Tokay Argan, M. (2009). Sanat Galerilerinin Sergi Salonunda Algılanan Hizmet Kalitesi Boyutları. Anadolu Üniversitesi Sosyal bilimler Dergisi 9(1), 1,18.

Wu, H. C. and Li, T. (2015). An Empirical Study of The Effects of Service Quality, Visitor Satisfaction, and Emotions on Behavioral İntentions of Visitors to The Museums of Macau. Journal of Quality Assurance in Hospitality \& Tourism, 16(1), 80-102.

Yılmaz, İ. (2011). Müze Ziyaretçilerinin Hizmet Kalitesi Algılamaları: Göreme Açık Hava Müzesi Örneği. Anatolia: Turizm Araştırmaları Dergisi, 22(2), 183-193.

Yücelt, U. (2000). Marketing Museums: An Empirical Investigation Among Museum Visitors. Journal of Nonprofit \& Public Sector Marketing, 8(3), 3-13. 